Review

\title{
Current Situation of Tetranychus urticae (Acari: Tetranychidae) in Northern Africa: The Sustainable Control Methods and Priorities for Future Research
}

\author{
Amine Assouguem 1,2(D), Mohammed Kara ${ }^{3}$ (D), Hamza Mechchate ${ }^{4 *(\mathbb{D})}$, Yesim Bulak Korkmaz ${ }^{5}$, \\ Safaâ Benmessaoud ${ }^{3}$, Amal Ramzi ${ }^{2}$, Khaled R. Abdullah ${ }^{6}$, Omar Mohammed Noman ${ }^{7}$, Abdellah Farah ${ }^{2}$ \\ and Abderahim Lazraq ${ }^{1}$
}

Citation: Assouguem, A.; Kara, M.; Mechchate, H.; Korkmaz, Y.B.;

Benmessaoud, S.; Ramzi, A.; Abdullah, K.R.; Noman, O.M.; Farah, A.; Lazraq, A. Current Situation of Tetranychus urticae (Acari: Tetranychidae) in Northern Africa: The Sustainable Control Methods and Priorities for Future Research. Sustainability 2022, 14, 2395. https://doi.org/10.3390/su14042395 Academic Editor: Sezai Ercisli

Received: 12 January 2022 Accepted: 16 February 2022 Published: 19 February 2022

Publisher's Note: MDPI stays neutral with regard to jurisdictional claims in published maps and institutional affiliations.

Copyright: (c) 2022 by the authors. Licensee MDPI, Basel, Switzerland. This article is an open access article distributed under the terms and conditions of the Creative Commons Attribution (CC BY) license (https:// creativecommons.org/licenses/by/ $4.0 /)$.
1 Laboratory of Functional Ecology and Environment, Faculty of Sciences and Technology, Sidi Mohamed Ben Abdellah University, Fez 30000, Morocco; assougam@gmail.com (A.A.); lazraqab@gmail.com (A.L.)

2 Laboratory of Applied Organic Chemistry, Faculty of Sciences and Technology, Sidi Mohamed Ben Abdellah University, Fez 30000, Morocco; ramzi.amal@usmba.ac.ma (A.R.); farah.abdellah1@gmail.com (A.F.)

3 Laboratory of Biotechnology and Conservation and Valorization of Natural Resources (LBCVRN) (ex LBPRN), Sidi Mohamed Ben Abdellah University, Fez 30000, Morocco; mohammed.kara@usmba.ac.ma (M.K.); safaa.benmessaoud@usmba.ac.ma (S.B.)

4 Laboratory of Inorganic Chemistry, Department of Chemistry, University of Helsinki, P.O. Box 55, FI-00014 Helsinki, Finland

5 Department of Plant Protection, Faculty of Agriculture, Ataturk University, Erzurum 25240, Turkey; yesim.bulak@atauni.edu.tr

6 Department of Medicinal Chemistry, Faculty of Pharmacy, Sana'a University, Sana'a 13078, Yemen; khaledraweh0@gmail.com

7 Department of Pharmacognosy, College of Pharmacy, King Saud University, Riyadh 11451, Saudi Arabia; onoman20@gmail.com

* Correspondence: Hamza.mechchate@helsinki.fi

\begin{abstract}
In North Africa, Tetranychus urticae Koch, 1836 represents one of the most destructive generalists among mite herbivores. Unfortunately, it is a source of important annual casualties in crop production. It is a phytophagous mite that can feed on hundreds of host plants and produces significant damage. The control of T. urticae in North Africa has been principally based on acaricide sprays. However, new alternative methods have shown effective results, such as artificial ultraviolet$\mathrm{B}$, natural enemies, and the introduction of new genetic methods. This review aims to present a synthesis of information surrounding control methods of T. urticae in North Africa. We highlight the principal findings of previous studies. Then, we discuss current control methods and propose new innovative research and sustainable approaches to controlling this pest. The control method can potentially extrapolate in North African regions due to its positive ecological results. Further, studies proved the use of natural enemies, myco-metabolites, bacteria metabolites, and the introduction of a genetic method in an integrated long-term sustainable program that can successfully defeat the populations of T. urticae. We also discuss high-priority research guidelines to investigate new sustainable management strategies. Setting up an integrated long-term ecological monitoring program in different Northwest African countries and incorporating new technologies into monitoring programs is an urgent need to fight this devastating pest.
\end{abstract}

Keywords: Tetranychus urticae; propagation; environment; crop protection; acaricide; biological control; integrated; management

\section{Introduction}

Maghreb countries share most of the phytosanitary problems [1]. North Africa's agricultural productivity is harshly restricted by multiple constraints. These constraints 
include lack of manpower, maturity of orchards, biotic, and abiotic constraints. The negative impact caused by pests reduces the quantity and quality of production. Indeed, spider mites, aphids, medflies, and diaspine scales are pests of primary economic importance [2]. When conditions are favorable and in the absence of adequate methods of control, significant damage is often observed on fruits, twigs, leaves, and young shoots [1]. The effective control of insects in food products has long been the object of producers and the industry sector [3]. Its pests are resistant to most groups of acaricides [4].

Tetranychus urticae Koch, 1836 (Acari: Tetranychidae) is one of the most important pest species that is widely distributed globally; it is a phytophagous mite from the family of Tetranychidae. This species is a highly polyphagous herbivore and a major agricultural pest worldwide that causes hard damages to economics. It is a cosmopolitan species [2]. It presents a notable pest of field crops, ornamentals, and annual and perennial plants [5,6]; it attacks (i) fruit species, including citrus, apple, pear shrubs, and raspberry [7], (ii) vegetables, including eggplant, cucumber, bean, okra, and tomato [8-11], (iii) ornamentals, especially dahlia, rose, gerbera, zinnia, and ganda [12]; and medicinal plants, such as moringa (Moringa oleifera), metel (Datura metel), Alfalfa (Medicago sativa), Peppermint (Mentha piperita), rosemary (Rosmarinus oflicinalis), and common vervain (Verbena oflicinalis) $[13,14]$.

In Egypt, T. urticae causes principal damage, such as defoliation, leaf yellowing, and leaf burning $[14,15]$, plus the indirect damage by diminishing photosynthesis, transpiration, and a significant decline in yield productivity [6,16]. In Morocco, T. urticae is undoubtedly remembered for its significant damages in agriculture and its redoubtable capacity to elaborate resistance to pesticides [17]; it causes qualitative and quantitative yield losses every agricultural season. All mobile stages of this mite preferentially feed on the lower surface of the leaf and extract the contents of mesophyll cells $[14,18]$. This pest attacks the cells of the parenchyma of which they absorb the contents with their cheliceral stylets, and provokes the appearance of yellow-greenish patches on the upper face of the leaves, thus producing the destruction of the foliage and the reduction of the period of filing of the ear [19]. Moreover, T. urticae causes severe damages in the Tunisian territory, particularly prevalent in the majority of orchards. During mid-March to June and from September to December; the citrus species of orange, lemon, tangerine, and pomelo are most susceptible [20].

Between mites' pests, T. urticae has the most significant proportion of pesticide resistance. In conventional chemical control management of T. urticae, broad-spectrum acaricides are often sprayed to diminish population levels. Nevertheless, they can additionally eliminate natural enemies, including auxiliary fauna [21]. Furthermore, multiple features of the spider mite biology, including incredibly high fecundity, rapid development, and haplodiploid sex determination, seem to facilitate the development of pesticide resistance [22]. The control of multi-resistant mites has become frequently difficult in North Africa [23]. This review aims to summarize North Africa's diverse current and prospective methods used to control T. urticae populations and motivate implementation of an integrated management strategy based on environmentally friendly practices, such as developing new biopesticides, physical control, or the use of a genetic approach. The goal of this study, on the one hand, is to describe the various control methods available for T. urticae in North African countries. On the other hand, it highlights the key findings from previous studies and overviews current and sustainable approaches used to manage this pest.

\section{Tetranychus urticae in North Africa}

Tetranychus urticae is a problematic pest of several global crops [24,25]. It is a generalist species that can feed on hundreds of host plants and produces significant damage to the field, greenhouse, and horticultural crops, as well as ornamental and fruit-bearing trees [26-29]. It can produce silk threads to protect itself from predators or to disperse from plant to plant. In Egypt, the generations of T. urticae follow one another at a rapid pace (approximately 27 generations per year) [30], T. urticae on Hood pear variety; the 
highest mean number of eggs laid by a female was $143.6 \mathrm{eggs} /$ female with a daily rate of 16.7 eggs/female/day at $30^{\circ} \mathrm{C}$ [31]. In Moroccan conditions, this pest presents an optimal development at temperatures of $30^{\circ} \mathrm{C}$. The female can generate a high number of eggs in a short time; for instance, on clementine, they can lay about 34 eggs in a period of 17 days (the biological cycle takes from 8 to 12 days in optimal condition) [32,33]. The drying up of leaves due to T. urticae, can negatively affect the crop's green matter (GM) yield. However, a reduction in potassium, nitrogen, and phosphorus has been detected on Chrysanthemum infested by T. urticae. Additionally, [19] observed a reduction in amylase activity and proteolytic enzyme, and reduced the total amount of proteins. In Tunisia, the economic importance of this mite has expanded on many crops, principally because of its resistance to acaricides [34]. Tetranychus urticae in citrus orchards are mainly active during summer and autumn. The highest population density is recorded in July and August. On lemon, the attack can be observed throughout the year if the winter is mild. The varieties of the clementine groups are the joint susceptible to mite attacks causing significant defoliation. In Algeria, T. urticae is listed as one of the most dangerous pests that cause immense damage to vegetable plants [35].

\section{Levels of Infestation and Severity of Spread}

Tetranychus urticae is a cosmopolitan pest. It occurs in most parts of the world; in Europe, Asia, Africa, Australasia, Caribbean islands, and North America [36]. Further, this pest is adapted to different climatic conditions. In North Africa, especially in Morocco, T. urticae is one of the most recorded pests on various crops, including fruit trees (apple and citrus) and spontaneous plants [37,38]. Similar results were cited in Algeria and Tunisia, which are under the same climatic conditions as Morocco [39]. In Egypt, spider mite was found in fruit trees and ornamental vegetation, causing serious damage, according to the infestation rates on these plants $[40,41]$. The differences in infestation rates can be attributed to the variation of environmental conditions, planting dates, and age of plantation [42].

Tetranychus populations multiply fast in the weeds and orchards surrounding vegetation and migrate to occupy the fruit trees [43]. This spread is not always passive but often takes place under the action of various stimuli counting temperature, wind, rainfall, and farming practices $[44,45]$. On clementine, a study was conducted in the Gharb region of Morocco, in which the orchards were isolated for three cropping annuals and without practice of acaricide treatments, in order to know the severity of infestation rate by T. urticae. This study showed that the infestation degree of the trees was 10\% in mid-April, to increase rapidly to $87 \%$ in July. According to this study, the spread occurs when the climatic conditions and the phenological development of the tree are favorable for the deployment of the mite [37]. T. urticae have been studied in Moroccan orchards over a period of ten weeks (from 25 March to 2 June 2002) on herbaceous strata and on two different varieties of apple trees ("Golden" and "Anna"). Adventitious plants such as Cuscuta epithymum, Malva neglecta, Sonchus asper, Convolvulus arvensis, and Urtica urens (and, to a lesser extent, Mentha pulegium, Sonchus oleraceus, Papaver rhoeas, and Sinapis arvensis) appear to be the most favorable host plants to T. urticae. Hence, they must be considered as potential sources of infestation for the fruit trees. In the North African countries, therefore, we suggest conducting this kind of research to estimate the infestation rates and propagation ways [46].

\section{Kind of Hosts}

Tetranychus urticae represents one of the most destructive generalists among mite herbivores [33]. It is considered a major pest decreasing plant growth and yield on different crops [47]. Among these, in North Africa, it attacks flowering plants and fruit crops, such as apricot, cherry (Prunus sp.), apple (Malus domestica), Citrus sp., strawberry (Fragaria ananassa), blackcurrant (Ribes nigrum), quince (Cydonia oblonga), plums (Prunus domestica), pear (Pyrus communis), cotton (Gossypium hirsutum), clover (Trifolium sp.), sunflower (Helianthus sp.), grapevine, eggplant (Solanum melongena), moringa (Moringa oleifera), melons, 
watermelons (Citrullus sp.), baby marrow (Zucchini sp.), cucumber (Cucumis sativus), green beans (Phaseolus vulgaris), carrots (Daucus carota), peanut (Arachis hypogaea), bindweed (Convolvulus aryensis), metel (Datura metel), alfalfa (Medicago sativa), peppermint (Mentha piperita), rosemary (Rosmarinus oflicinalis), common vervain (Verbena oflicinalis), and (Rosa sp.) have been recorded [31,48,49].

\section{Control Methods}

\subsection{Chemical Control}

In the commercial orchards of Northern Africa, the protection against pests is currently assured by preventive and intensive chemical control. Despite benefits such as rapid action in the reduction of pests numbers and their easy use when compared to natural extracts from plants [50], this strategy has many limitations; the examination of the action spectrum of the active components used throughout the world reveals that $46 \%$ of acaricides, $72 \%$ of insecticides, and $28 \%$ of fungicides are globally toxic towards auxiliary arthropods and public health [51]. Additionally, spider mites have developed resistances to more than 80 acaricides in more than 60 countries [34]. Particularly, Tetranychus urticae has developed resistances to more than 30 organophosphates and carbamates in 40 countries, this resistance is due to mutations in the mitochondrial cytochrome $b$ protein of this pest [52]. Besides, a non-rational application of benomyl [methyl 1-(butylcarba-moyl) benzimidazole-2-ylcarba- mate] and other pesticides killed all noticeable predators of the pest [53]. Therefore, the absence of control by natural enemies due to their death by pesticides can cause a considerable increase in T. urticae populations [54].

In Morocco, the Spirodiclofen (240 g/L), Malathion $(440 \mathrm{~g} / \mathrm{L})$, Abamectine $(18 \mathrm{~g} / \mathrm{L})$, Bifenazate (480 g/L), Fenpyroximate (51,2 g/L), Fenazaquin (200 g/L), Tébufenpyrad (20\%), Propargite (57\%), Milbémectine (1\%), Bifenthrine (100 g/L), Clofentézine (500 g/L), Pyridabène $(100 \mathrm{~g} / \mathrm{L})$, Maltodextrine $(27 \%)$, and Dicofol $(18,5 \%)$ are the most acaricides used to control the tetranychid mites in greenhouses and orchards [55]. In the Loukkos Morocco area, to prevent the T. urticae, the majority of strawberry plants are treated with Abamectin [2,54]. In Tunisia, the main acaricides used to fight T. urticae on diverse crops are Hexythiazox 10\% WP, Fenpyroximate $50 \mathrm{~g} / \mathrm{L} \mathrm{SC}$, Abamectin $18 \mathrm{~g} / \mathrm{L}$ EC, and Pyrethrin $40 \mathrm{~g} / \mathrm{L}$ EC [56]. In Egypt, the use of the Abamectin revealed excellent results and important toxicity on T. urticae [57]. However, the intensive Abamectin applications have diminished the efficacy and shortened their effect, indicating a potential resistance development problem [57,58]. The effects of acaricides on T. urticae are extensively studied $[59,60]$. The intensive and abusive use of acaricides to control this mite has driven an increasingly important resistance against carbamates, cyclodiene organochlorine, organophosphates pyrethroids, organotin miticides, benzoylureas, organochlorines, hydrazine carbazate, macrocyclic lactones, and other chemical products [61]. Other effects have been noticed, such as alterations in the physiology and biology of living organisms and modification of fecundity and behavior [62]. To overcome this difficulty, the experts are constantly exploring new products based on biological control, particularly biopesticides [23,63].

\subsection{Biological Control}

Biological control agents such as bacteria, predatory insects, or fungi can be used as alternative approaches for control [64]. Bacterial organisms, such as Yersinia entomophaga, Xenorhabdus spp. Pseudomonas entomophila, Burkholderia spp. Chromobacterium spp. Streptomyces spp. Saccharopolyspora spp., and Bacillus spp. have all recently gained commercial interest for the production of diverse metabolites that act as effective insecticides [65]. Secondary metabolites of fungi, such as Aspergillus melleus, Emericella nidulans G. Winter, 1884, Alternaria terreus, Chaetomium globosum, Trichoderma viridae, and Eurotium eurotiorum are a promising source of control against various agricultural pests [66].

The most important predators that have significantly managed T. urticae and other spider mites are Amblyseius swirskii (Athias-Henriot, 1962), Typhlodromus rhenanoides (Athias Henriot, 1960), Phytoseiulus persimilis (Athias-Henriot, 1957), Typhlodromus phialatus (Athias 
Henriot, 1960), Neoseiulus cucumeris (Oudemans, 1930), Neoseiulus stolidus (Chaudhri, 1968), Feltiella acarisuga (Vallot, 1827), Scolothrips longicornis (Priesner, 1926), Euseius scutalis (Athias Henriot, 1958), Euseius stipulates (Athias Henriot, 1960), and Stethorus punctillum (Julius Weise, 1891) [5,59].

\subsubsection{Myco-Metabolites}

The fungal isolates of Aspergillus melleus, Emericella nidulans, Chaetomium globosum, and Aspergillus terreus presented practical control activities against females and eggs of two-spotted spider mite [66]. The effect of culture filtrates of fungal isolates showed mortality rates of $52.4 \%, 52.4 \%, 48.4 \%$, and $50.4 \%$, exhibited by Alternaria terreus, A. alternata, Trichoderma viridae, and Eurotium eurotiorum, respectively [67]. Further, the laboratory evaluation showed these secondary metabolites of $A$. melleus; (nodulisporic acid, mellamide; ochratoxin C, 7-oxocurvularin,6-(4'-hydroxy-2'-methyl phenoxy)- (-)-(3R)-mellein and 7-oxocurvularin can be used as biopesticides in the biological control of T. urticae [66]. Similarly, the Azadirachta indica (neem oil) extract registered that the mortality proportion of adults was $100 \%$ at all tested concentrations after $72 \mathrm{~h}$ of application [68]. In Spain, Beauveria bassiana gave impressive results in the control of T. urticae, and therefore is a candidate to be included in integrated pest management programs with triflumuron against T. urticae [69].

\subsubsection{Bacterial Metabolite}

The essential secondary metabolites implicated in biocontrol by fluorescent pseudomonads are pyoluteorin (PLT), phenazines (PHZ), 2, 4-diacetylphloroglucinol (DAPG), cyclic lipopeptides (CLPs), pyrrolnitrin (PRN), and volatile natural composites (VOCs) such as hydrogen cyanide (HCN). These metabolites are recognized for antibacterial, antifungal, antiviral, antitumor, and antinematicidal properties [63]. A study in Morocco at the laboratory showed that all three fluorescent pseudomonas isolates Q110B, Q036B, and Q172B from tomato rhizospheric soil were potential biological control agents for T. urticae. In particular, Pseudomonas fluorescens isolate Q036B was the most promising applicant for biological control of T. urticae with a mortality rate of approximately $99 \% 72 \mathrm{~h}$ after application. For the other two strains (Q172B and Q110B), the mortality rates were similar $72 \mathrm{~h}$ after application and varied from 54 to $89 \%$ [23]. Besides, the $P$. fluorescens produces bacterial chitinases, which are efficient in controlling the mites by hydrolyzing their chitinous exoskeleton, the culture with cent percent of $P$. fluorescens produced $100 \%$ mortality of spider mite in $24 \mathrm{~h}$ after application, whereas $75 \%$ culture yielded $100 \%$ mortality in $72 \mathrm{~h}$, when 48 h, 50\% culture was found to be least effective [70]. In Turkey, under laboratory conditions, Pseudomonas putida isolated from tomato soils produced high mortality rates of T. urticae. This bacterial application significantly diminished the total number of eggs and egg hatch compared to the control [71]. Thus, multiple Agrobacterium strains, Streptomyces, Bacillus, Pseudomonas, Alcaligenes, and others have been notified as help bacterial control agents. To fight against pests, they employ many biotechniques, for example competition, parasitism, antibiosis, and cross-protection [72,73].

\subsubsection{Protectants Plant-Incorporated (PIP)}

The extracts of plants are remarkably rich in toxins and inhibitors and can be the source of many insecticidal and acaricidal substances exploitable in the control of pests [74,75]. Black soap, brown in color, is biodegradable, non-polluting, and an excellent insecticide. This product is active on some insects such as mealy bugs, aphids, whiteflies, thrips, mites, etc. Through simple contact, it asphyxiates them while blocking the respiratory pores. Besides, it does not produce toxic residues and does not affect natural predators. These products are authorized by the specifications of organic agriculture (EEC regulation 2092/91) [76,77]. A study conducted in the Saïs region of Morocco showed that black soap was effective against several pest populations on the bell pepper crop compared to the control block [77]. 
The utilization of Sulfur on tomato leaves diminished T. urticae from $31.5 \pm 6.5$ individuals / 15 leaves before treatment to $4 \pm 0.3$ [78]. This reinforces the results observed on the grapevine [79], according to which sulfur can be used to control mites while presenting low toxicity to predators. Another study under laboratory conditions confirms that sulfur is toxic against eggs of T. urticae [80]. In the field, the lime sulfur reduced T. urticae fecundity and fertility. It showed selectivity against naturally occurring predatory mites, which increases its potential as a mechanism for integrated mite management [78].

The pesticide effects of the diverse specific components of Achillea mellifolium essential oil have been assessed in recent studies. Piperitone [81], cymene, borneol [82], bornyl acetate [83], 1,8-cineole, $\alpha$-pinene [84], $\alpha$-terpinolene [85], camphene [86], $\alpha$-terpinene [87], and carvacrol [88] revealed prospective pesticidal effects. Besides, the susceptibility of T. urticae to some monoterpenes has been reported [82,84,86,89]. According to the apparent results in the laboratory condition, it can be concluded that the major component of essential oil of $A$. millefolium is responsible for the acaricidal action against T. urticae and may be useful in the exploration of the effective natural products such as acaricide [90]. Mentha sp. essential oils can be used in sustainable pest control. In Egypt, under greenhouse conditions, Mentha longifolia showed $100 \%$ toxicity to T. urticae [91]. In Algeria, the essential oils obtained from Mentha spicata presented a better insecticidal impact against most pests [92]. The sesquiterpenoids isofuranodiene and germacrone from the crucial oil of Smyrnium olusatrum (Apiaceae) recorded significant oviposition inhibition, and they can be used to produce adequate acaricides [93]. In Tunisia, field experiments, the extracts of three plant species (Allium sativum, Allium cepa, and Deverra scoparia) produced an effective control of T. urticae population more than 15 days compared with the untreated control and with classical synthetic acaricides (spirodiclofen and fenbutatin oxide) [75,94]. Besides, the tests have revealed that the extract of $A$. sativum was efficient on the population of T. urticae was diminished to 1.7 mites per leaf for more than 21 days after treatment compared with the untreated control at 3.7 mites per leaf [50].

The laboratory tests showed that the fumigant toxicity of 24 essential oils from lemon eucalyptus was effective against females of T. urticae menthol being the maximum toxic compound, followed by citronellyl acetate [95]. The two eucalyptus essential oils, specifically Eucalyptus lehmani and Eucalyptus astringens, showed a positive effect against strains from Tunisia and Algeria of three stocked beetles: Rhyzopertha dominica, Callosobruchus maculatus, and Tribolium castaneum [96]. In Tunisia, the ten principal constituents of Deverra scoparia oil were individually tested against T. urticae females. The greatest toxicity was found with alpha-pinene, 3-carene, and terpinen-4-ol. pinene. The presence of all elements together in the artificial mixture caused a notable reduction in the number of eggs laid by females of T. urticae. The essential oil of D. scoparia showed that female mortality increased with growing oil concentrations, and a decline in fecundity had been observed. Deverra scoparia might add to the arsenal of programs for controlling mites in open field and in greenhouses. However, further studies are needed to evaluate the cost, efficiency, and safety of the oil, besides knowing each constituent's role in the toxicity and effects on fecundity [97]. In laboratories growing wild in the Mediterranean area, the mortality rates of $95-100 \%$ were observed at all the sage oil dosages and when rosemary emulsions contained at least $0.20 \%$ essential oils [98]. In the laboratory sage, the essential oil had raised mortality (toxicity to adult females of T. urticae) and diminished fecundity (production and viability of eggs) [98]. The essential oils lose their force against environmental conditions. Nanoformulation is a method that may preserve the pesticide performance of plant essential oils. The Chitosan nanocapsules loaded with the essential oil of Achillea millefolium against adult T. urticae showed a beneficial effect [99].

\subsubsection{Control with Predators}

The main predators encountered in North Africa are Typhlodromus rhenanoides, Phytoseiulus persimilis (Athias-Henriot), 1957, Typhlodromus phialatus, Neoseiulus cuc- 
umeris, Neoseiulus stolidus, Feltiella acarisuga, Scolothrips longicornis, Euseius scutalis, and Euseius stipulatus.

\section{Phytoseiulus persimilis (Athias-Henriot, 1957)}

Phytoseiulus persimilis (Acari: Phytoseiidae) is a specialist predator that feeds particularly on Tetranychus species and whose survival depends on the presence and quality of its prey [50]. In Morocco, P. persimilis is the principal predators of T. urticae in the open field and in greenhouses [100], according to faunal estimations performed in 2009-2010 on strawberry plants in the Loukkos region which revealed that the mite pest T. urticae and its natural enemy, the predatory mite P. persimilis, are habitually encountered [2]. In Egypt, this predator is one of the most significant biological control agents against the two-spotted spider mite. This predator can control T. urticae on different crops when it releases at low infestation [6]. In Turkey, the greenhouse tests were conducted to discover the efficiency of single and combined releases of two predatory, P. persimilis and Neoseiulus californicus (McGregor, 1954) to control the T. urticae on the Soybean plant; the authors concluded that releasing of $P$. persimilis was the best control method among the other combined releases tested to control spider mites. The similar results were found [101] in Spain, the release of P. persimilis alone was better than combined releases. Generally, P. persimilis is an efficient natural enemy in the Mediterranean greenhouse crops to the mite T. urticae [102].

\section{Neoseiulus californicus McGregor, 1954}

The Neoseiulus californicus (Acari: Phytoseiidae) is a cosmopolitan species of Mediterranean climates that tolerate the higher temperatures of semi-arid to arid areas [103,104]. In Egypt, the N. californicus is the natural enemies associated with T. urticae [57]. In Morocco, the predatory mite N. californicus feeds on all stages of the weaver mite T. urticae on citrus crops [105]. In Tunisia, the N. californicus is a predatory Phytoseiidae widely utilized in integrated pest management programs to control the tetranychid mites in citrus, apple, fruit, and vegetable crops [106]. This predator plays a key role in the regulation of T. urticae in Spanish citrus orchards [107].

\section{Euseius stipulates Athias-Henriot, 1960}

This species was described from North Africa in Algeria, Morocco, Tunisia [108]. It feeds on the red spider and eriophyid mites and consumes pollen [108]. In Tunisia, E. stipulatus was the most abundant species found on citrus trees (82\%) [20]. Generally, this species is well represented in Mediterranean citrus orchards [109].

\section{Combined Releases}

In Egypt, the releasing of predators Chrysoperla carnea (Steph, 1836), Orius albidipennis (Reuter, 1884), and P. persimilis showed significant control of T. urticae, and it also assured increased crop yield as compared to pesticide application [110]. In Morocco, the new introduction in citrus orchards, such as the predators Neoseiulus californicus and Amblyseius swirskii against Eutetranychus orientalis (Klein, 1936) and T. urticae have produced good results [111]. Similarly, in Spain, the control of T. urticae through releases of the predatory mites Phytoseiulus persimilis, Neoseiulus californicus, Amblyseius swirskii, and Orius laevigatus Fieber, 1860 (Hemiptera: Anthocoridae) showed significant results. Besides, the combined release of O. laevigatus with $A$. swirskii gave efficient control of sweet pepper principal pests [112]. The use of F. acarisuga (Diptera: Cecidomyidae) and S. longicornis (Thysanoptera: Thripidae) play an important role in the control of spider mites populations in different crops [113]. In Spain, Stethorus punctillum (Weise, 1891) is an important predator of spider mites, especially Panonychus citri (McGregor, 1916) and T. urticae in citrus orchards [114]. Amblyseius andersoni (Acari: Phytoseiidae) is an important predator species found in multiple crops. The nymphs and adults of $A$. andersoni are predaceous, feeding on different spider mite species [115]. A study confirmed that the use of this predator alone or in combination with other phytosides mites provides better control of spider mites [116]. 


\subsection{Physical Control}

Integrated pest management should rely on an array of tactics. In reality, the use of physical control methods must be part of an integrated pest management approach. Physical controls can be classified as passive (e.g., fences, organic mulch, trenches, particle films, inert dust, and oils), active (e.g., thermal shocks, electromagnetic radiation, mechanical shocks, and pneumatic control), and miscellaneous (e.g., cold storage, heated air, flaming, hot-water immersion) [117]. Some physical methods such as oils have been used successfully for preharvest treatments for decades [118]. Another recently invented method for preharvest situations is particle films [119]. As we move from production to the consumer, legal constraints restrict the number of alternatives available. Consequently, several physical control methods are used in postharvest situations. Two notable examples are the entoleter, an impacting machine used to crush all insect stages in flour [120], and hot-water immersion, used to kill tephritid fruit flies [121].

Over the past decade, UV Perspective, the solar and artificial ultraviolet-B (UVB) radiation, has frequently been shown to exert deleterious impacts on the survival and egg production of mites [122]. The eggs and larvae of T. urticae are more vulnerable to UVB radiation than adult females, and mortality is directly proportional to the cumulative UVB irradiance [123]. Additionally, using the ultraviolet-B method control of spider mites showed excellent results, especially for greenhouse horticultural crops such as strawberries; performing it is a favorable IPM strategy [124]. Conversely, the enhanced UV-B radiation increases the deleterious effects on insect behavior and health and affects their interactions with plants via induction of defensive material products and photomorphogenic variations. Insect suction devices, insect glue, and electromagnetic energy suppress insect populations. Generally, the physical control methods are environmentally safe, fit well into IPM strategies, and significantly reduce chemical control [125]. These methods are not yet explored in North Africa, but with the similarity of Mediterranean context recorded, we suppose that the good results documented in South Europe could be extrapolated to North Africa.

\subsection{Genetic Control}

Genetic control is one of the methods that can replace the application of insecticides [126]. The examination of the sequenced genome of T. urticae will reveal the resistance mechanisms used by the mites. Moreover, the complete sequencing revealed that this genome, considered small with its 90 million bases, includes unique genes that have not yet been identified in other arthropods [17]. The researchers also identified numerous genes implicated in detoxification and digestion of toxins, which help explain the mite's unparalleled resistance to toxic compounds produced by certain plants to defend themselves, opening up the prospect of developing naturally resistant plants [127].

\subsection{Integrated Pest Management of Tetranychus Urticae}

Integrated pest management through predator and a compatible synthetic acaricide may provide an alternative strategy to chemical control of the pest [128]. Experiments were conducted on greenhouse roses to evaluate the efficacy of the nC24 petroleum spray oil (PSO), D-C-Tron in combination with Phytoseiulus persimilis (Acarina: Phytoseiidae) against Tetranychus urticae in the context of developing an integrated management program. Results showed that $0.5 \%$ PSO applied fortnightly to roses provided excellent protection against T. urticae infestation and did not affect the population density of P. persimilis in the upper and lower foliage [129]. In Brazil, on strawberry crops, control of T. urticae in the program based on release of Neoseiulus californicus (McGregor) and reduction of the frequency of acaricide applications (IPM) was effective in maintaining a significantly lower level of pest infestation, resulting in a six-fold reduction in the frequency of acaricide applications and, consequently, a reduction in selection pressure for acaricide resistance [130]. Another field experiment in hops using b-acid sprays with a release of the predatory mite P. persimilis ensured significant control of T. urticae [131]. 


\section{Conclusions}

This review highlights the current knowledge and prospects of sustainable control approaches against T. urticae used in North Africa, to clarify the current situation of this pest and inspire specialists in other countries to control it. In addition, it serves as a roadmap for scientists to expand their research. In terms of plant protection, it is clear from the discussions, developed in our study, that integrated pest management remains the most appropriate sustainable method for better crop protection. Practiced by the majority of Maghrebian countries, chemical control is the most widely used method in commercial agriculture. This is essentially due to economic and technical reasons. Henceforth, the control methods must be based on the use of biopesticides, genetic control, and physical control in an integrated long-term sustainable program. The development of physical control provides interesting opportunities as mechanical control, thermal control, electromagnetic control, and pneumatic controls. Their inclusion in an integrated pest management program can contribute greatly to the achievement of the pesticide reduction objectives set by several countries and organizations. In this context, responsible agricultural organizations should actively support the development and implementation of physical control methods in integrated pest and plant protection management programs. Genetic modifications of plants and mites could be performed to improve the molecular mechanisms that control the plant-mite interplay. An advanced understanding of the mite-plant interaction will be an effective tool for protection. The advances are also expected in light of pest control due to these technological developments in lighting. Finally, the current trend is to combine all these methods in an integrated pest management strategy. These programs must take into count the climate conditions, phenology of pests, infestation rates, and propagation speed of pests in each North African country. All these elements are suggested to control pests, respect the environment and public health.

Author Contributions: Conceptualization, A.A. and A.L.; methodology, M.K., A.R., S.B. and Y.B.K.; data curation, H.M.; writing-original draft preparation, A.A.; writing-review and editing K.R.A. and O.M.N.; supervision, A.L. and A.F. All authors have read and agreed to the published version of the manuscript.

Funding: This research was funded by the Deanship of Scientific Research Sana'a University.

Institutional Review Board Statement: Not applicable.

Informed Consent Statement: Not applicable.

Data Availability Statement: Data are available upon request.

Acknowledgments: Open access funding provided by University of Helsinki.

Conflicts of Interest: The authors declare no conflict of interest.

\section{References}

1. La FAO et l'UMA Signent Un Accord d'assistance Technique Pour Lutter Contre Les Ravageurs et Les Maladies Des Cultures En Afrique Du Nord. 2016. Available online: https:/ / www.fao.org/neareast/news/view/fr/c/418095/ (accessed on 30 January 2022).

2. $\quad$ Lagziri, M.; Benicha, M.; M'rabet, R.; Amrani, A. El Influence de l'usage Préventif Des Pesticides Sur Les Acariens Tetranychus urticae et Phytoseiulus persimilis (Acari: Tetranychidae, Phytoseiidae) Présents En Cultures de Fraisiers Du Nord Du Maroc. Biotechnol. Agron. Soc. Environ. 2015, 19, 355-363.

3. Xue, W.; Snoeck, S.; Njiru, C.; Inak, E.; Dermauw, W.; Van Leeuwen, T. Geographical Distribution and Molecular Insights into Abamectin and Milbemectin Cross-Resistance in European Field Populations of Tetranychus urticae. Pest Manag. Sci. 2020, 76, 2569-2581. [CrossRef] [PubMed]

4. Vacante, V. The Handbook of Mites of Economic Plants: Identification, Bio-Ecology. Available online: https://books.google. co.ma/books?hl=fr\&lr=\&id=yc4_CwAAQBAJ\&oi=fnd\&pg=PR3\&dq=Vacante+V.+2016+---+The+handbook+of +mites+of + economic+plants++Wallingford:+CABI+Publishing.+p\&ots=owucks8JhR\&sig=1Q-_htz0V9EuSINyaxQ7C7D9RPs\&redir_esc= $\mathrm{y} \# \mathrm{v}=$ onepage $\& \mathrm{q} \& \mathrm{f}=$ false (accessed on 17 October 2021).

5. Sim, C.; Seo, E.; Cho, K. Life Table and Sensitivity Analysis as Fitness Evaluation Method of Fenpyroximate and Pyridaben Resistant Twospotted Spider Mite (Tetranychus urticae Koch). J. Asia-Pac. Entomol. 2003, 6, 193-199. [CrossRef] 
6. Seham, A.; El-Dein, E.; Azouz, H.A.A.; Amira, E.M.; Doaa, A.A.E.-A. Provided for Non-Commercial Research and Education Use. Not for Reproduction, Distribution or Commercial Use. Hepatoprotective Agents Rats 2020, 12, 25-40.

7. Mariéthoz, J.; Baillod, M.; Christian Linder, P.; Antonin, C.M. Distribution, Méthodes de Contröle et Stratégies de Lutte Chimique et Biologique Contre l' Acarien Jaune, "Tetranychus urticae" Koch, Dans Les Cultures de Framboisiers-Dialnet. Available online: https:/ / dialnet.unirioja.es/servlet/articulo?codigo=2984817 (accessed on 16 April 2021).

8. Gulati, R. Incidence of Tetranychus cinnabarinus (Boisd.) Infestation in Different Varieties of Abelmoschus Esculentus L. Available online: https: / / agris.fao.org/agris-search/search.do?recordID=IN2004000229 (accessed on 16 April 2021).

9. Reddy, G.V.P.; Baskaran, P. Damage Potential of the Spider Mite Tetranychus ludeni (Acari: Tetranychidae) on Four Varieties of Eggplant. Int. J. Trop. Insect Sci. 2006, 26, 48-56. [CrossRef]

10. Acari, K.; Tomato, T. Growth Stage Based Economic Injury Levels for Two Spotted Spider Lycopersicon Esculentum Mill. Trop. Agric. Res. 2010, 22, 54-65.

11. Haque, M.; Islam, T.; Naher, N.; Mainul Haque, M. Seasonal Abundance of Spider Mite Tetranychus urticae Koch on Vegetable and Ornamental Plants in Rajshahi. Univ. J. Zool. Rajshahi Univ. 2011, 30, 37-40. [CrossRef]

12. Silva, E.A.; Reis, P.R.; Carvalho, T.M.B.; Altoé, B.F. Tetranychus urticae (Acari: Tetranychidae) on Gerbera Jamesonii Bolus and Hook (Asteraceae). Braz. J. Biol. 2009, 69, 1121-1125. [CrossRef] [PubMed]

13. Logan, J.G.; Birkett, M.A. Juvenile Hormonal Activity of Mono- and Polyenehomobenzenes in Drosophila virilis, Spodoptera Frugiperda and Araschnia Levana. Pest Manag. Sci. 2007, 63, 809-814. [CrossRef]

14. Abdallah, A.M.; Ismail, M.S.M.; AboGhalia, A.H.; Soliman, M.F.M. Factors Affecting Population Dynamics of Tetranychus urticae and Its Predators on Three Economic Plants in Ismailia, Egypt. Int. J. Trop. Insect Sci. 2019, 39, 115-124. [CrossRef]

15. Youssef, A.T.A.; El-Badry, E.A.; Heykal, I.H. Mites Inhabiting Cotton and Associated Weeds in Egypt (Acarina). Available online: https:/ /agris.fao.org/agris-search/search.do?recordID=US201301297861 (accessed on 17 April 2021).

16. Shaabow, A.; Ahmad, M.; Zidan, R. The Biological Control of Two Spotted Spider Mites Using the Predatory Mite on Bean Grown under Greenhouse Conditions. Int. J. Agric. Environ. Sci. 2019, 6, 63-69. [CrossRef]

17. Grbić, M.; Van Leeuwen, T.; Clark, R.M.; Rombauts, S.; Rouzé, P.; Grbić, V.; Osborne, E.J.; Dermauw, W.; Ngoc, P.C.T.; Ortego, F.; et al. The Genome of Tetranychus urticae Reveals Herbivorous Pest Adaptations. Nature 2011, 479, 487-492. [CrossRef] [PubMed]

18. Nachman, G.; Zemek, R. Interactions in a Tritrophic Acarine Predator-Prey Metapopulation System V: Within-Plant Dynamics of Phytoseiulus persimilis and Tetranychus urticae (Acari: Phytoseiidae, Tetranychidae). Exp. Appl. Acarol. 2003, 29, 35-68. [CrossRef]

19. Fakhour, S. L'acarien Jaune, Tetranychus urticae Koch. (Acari: Tetranychidae) Sur Maïs Fourrager Au Maroc: Impact et Stratégies de Lutte. In Proceedings of the Deuxième Colloque sur les Acariens des Cultures, Montpellier, France, 24-25 October 2005.

20. Sahraoui, H. Influence Des Pratiques Agro-Écologiques et de La Protection Phytosanitaire Sur Les Communautés d'acariens Phytoseiidae (Acari: Mesostigmata) Dans Les Vergers Agrumicoles Tunisiens. Available online: https://www.supagro.fr/theses/ extranet/12-0026_Sahraoui.pdf (accessed on 17 June 2021).

21. Attia, S.; Gratia, E.; De Herde, A.; Hensen, J.L.M. Simulation-Based Decision Support Tool for Early Stages of Zero-Energy Building Design. Energy Build. 2012, 49, 2-15. [CrossRef]

22. Lu, W.; Wang, M.; Xu, Z.; Shen, G.; Wei, P.; Li, M.; Reid, W.; He, L. Adaptation of Acaricide Stress Facilitates Tetranychus urticae Expanding against Tetranychus cinnabarinus in China. Ecol. Evol. 2017, 7, 1233-1249. [CrossRef] [PubMed]

23. Qessaoui, R.; Bouharroud, R.; Amarraque, A.; Ajerrar, A.; El Hassan, M.; Chebli, B.; Dadi, M.; Elaini, R.; El Filali, F.; Walters, A.S Ecological Applications of Pseudomonas as a Biopesticide to Control Two-Spotted Mite Tetranychus urticae: Chitinase and HCN Production. J. Plant Prot. Res. 2017, 57, 409-416. [CrossRef]

24. Tsagkarakou, A.; Pasteur, N.; Cuany, A.; Chevillon, C.; Navajas, M. Mechanisms of Resistance to Organophosphates in Tetranychus urticae (Acari: Tetranychidae) from Greece. Insect Biochem. Mol. Biol. 2002, 32, 417-424. [CrossRef]

25. Tehri, K. A Review on Reproductive Strategies in Two Spotted Spider Mite; AkiNik Publications: New Delhi, India, 2014; Volume 2, pp. 35-39.

26. Overmeer. Alternative Prey and Other Food Resources. Spider Mites Biol. Nat. Enemies Control 1985, 1, $131-139$.

27. Sedaratian, A.; Fathipour, Y.; Moharramipour, S. Comparative Life Table Analysis of Tetranychus urticae (Acari: Tetranychidae) on 14 Soybean Genotypes. Insect Sci. 2011, 18, 541-553. [CrossRef]

28. Jafari, S.; Fathipour, Y.; Faraji, F. Temperature-Dependent Development of Neoseiulus barkeri (Acari: Phytoseiidae) on Tetranychus urticae (Acari: Tetranychidae) at Seven Constant Temperatures. Insect Sci. 2012, 19, 220-228. [CrossRef]

29. Golizadeh, A.; Ghavidel, S.; Razmjou, J.; Fathi, S.A.A.; Hassanpour, M. Comparative Life Table Analysis of Tetranychus urticae Koch (Acari: Tetranychidae) on Ten Rose Cultivars. Acarologia 2017, 57, 607-616. [CrossRef]

30. Gutierrez, J. Etude Biologique et Écologique de, Tetranychus neocaledonicus André (Acariens, Tetrmychidae); ORSTOM: Paris, France, 1976.

31. Luo, Z. Analysis of the effect of reasonable close planting on respiration characteristics of alfalfa (Medicago sativa 1.) artificial grassland. Turk. J. Agric. For. 2021, 45, 533-540. [CrossRef]

32. Allam, L.; Hmimina, M. Potentialités de Développement De Tetranychus urticae Koch (Tetranychidae, Acari) Sur Quelques Hôtes Sauvages et Cultivés. Rev. Maroc. Des Sci. Agron. Et Vétérinaires 2011, 14, 37-44.

33. Golan, K.; Jurado, I.G.; Kot, I.; Górska-Drabik, E.; Kmieć, K.; Łagowska, B.; Skwaryło-Bednarz, B.; Kopacki, M.; Jamiołkowska, A. Defense Responses in the Interactions between Medicinal Plants from Lamiaceae Family and the Two-Spotted Spider Mite Tetranychus urticae Koch (Acari: Tetranychidae). Agronomy 2021, 11, 438. [CrossRef] 
34. İçli, N.; Tahmas Kahyaoğlu, D. Investigation of pesticide residues in fresh sultani grapes and antioxidant properties of fresh/sundried/oven-dried grapes. Turk. J. Agric. For. 2020, 44, 350-360. [CrossRef]

35. Farida, B. Usages Des Produits Phytosanitaires Dans Les Cultures Sous Serres Des Ziban (Algérie) et Évaluation Des Conséquences Environnementales Possibles. Ph.D. Thesis, Université Mohamed Kheider-Biskra, Biskra, Algeria, 2017; pp. $2016-2017$.

36. Migeon, A.; Nouguier, E.; Dorkeld, F.; Cbgp, U.M.R.; Ird, I.; Montpellier, C.; Cedex, M. Trends in Acarology. Trends in Acarology: Proceedings of the 12th International Congress; Springer: Dordrecht, The Netherlands, 2010; pp. 557-560. [CrossRef]

37. Hmimina, M.; Allam, L.; Ougass, Y.; Marmouche, A. Circonstances Des Pullulations de Tetranychus urticae Koch (Tetranychidae: Acarina) En Verger d'agrumes. IOBC/Wprs Bull. 1995, 18, 35.

38. Naher, N.; Islam, W.; Haque, M.M. Predation of Three Predators on Two-Spotted Spider Mite, Tetranychus urticae Koch (Acari: Tetranychidae). J. Life Earth Sci. 2005, 1, 1-4.

39. FAO Strategie en Afrique FAO 2018-2021. 2018. Available online: Https://www.fao.org/documents/card/fr/c/04da353a-9da5 -407a-8401-b5a920390a9b/ (accessed on 2 January 2022).

40. Mohammed, K.; Karaca, İ; Agarwal, M.; Newman, J.; Ren, Y. Age-specific life tables of Aonidiella aurantii (Maskell) (hemiptera: Diaspididae) and its parasitoid Aphytis melinus debach (hymenoptera: Aphelinidae). Turk. J. Agric. For. 2020, 44, 180-188. [CrossRef]

41. Baiomy, F. Efficiency of Modern Methods for Controlling Some Vegetable Pests in Greenhouses in Egypt and Morocco. Ph.D Thesis, Cairo University, Caire, Egypt, Ins. African Res. Studies. 2008; pp. 154-157. Available online: https:/ / scholar.google.com/scholar?hl=fr\&as_sdt=0\%2C5\&q=Baiomy $\% 2 C+$ Fatina $\% 2 C+A .+M .+2008 .+$ Efficiency + of + modern + methods+for+controlling+some+vegetable+pests+in+greenhouses+in+Egypt+and+Morocco.PhD+.Thesis $\% 2 \mathrm{C}+\mathrm{Ins} .+\mathrm{African}+$ Res.+Studies\%2C+Cairo+Univ.+154pp.+7 (accessed on 28 June 2021).

42. Shalaby, F.F.; Ali, F.A.; Hafez, A.A.; Saad, H.M. Planting Date in Relation To Insect and Animal Pests Attacking Cucumber Plants Under Protected Cultivation At Giza Governorate. Egypt. J. Agric. Res. 2013, 91, 1347-1360. [CrossRef]

43. Brandenburg, R.L.; Kennedy, G.G. Intercrop Relationships and Spider Mite Dispersal in a Corn/Peanut Agro-Ecosystem. Entomol. Exp. Et Appl. 1982, 32, 269-276. [CrossRef]

44. Gerson, U.; Aronowitz, A. Feeding of the carmine spider mite on seven host plant species. Entomol. Exp. Et Appl. 1980, 28, 109-115. [CrossRef]

45. Chandler, L.D.; Archer, T.L.; Ward, C.R.; Lyle, W.M. Influences of Irrigation Practices on Spider Mite Densities on Field Corn. Environ. Entomol. 1979, 8, 196-201. [CrossRef]

46. Vicente, C.; Joutei, A.B.; Lebrun, P. What Strategies to Use against Mite Pests of Apple in Morocco? Parasitica 2004, 59, 25-41.

47. Farouk, S.; Osman, M. Alleviation of Oxidative Stress Induced by Spider Mite Invasion through Application of Elicitors in Bean Plants. Egypt. J. Biol. 2012, 14, 1-13. [CrossRef]

48. Saba, F. (Chef du Laboratoire d'Entomologie, Phytiatlie, Direction de la Recherche Agronomique, Rabat, Maroc.). Aux Plantes Cultiv. Au Maroc. 1973, 49, 69-97.

49. Abo-Elmaged, T.M.; Ali, A.W.M.; Abdel-Rahman, M.A.A.; Abd-Allah, A.H.A. Activity of the Two Spotted Spider Mite, Tetranychus urticae (Koch) (Acari) Infesting Cucumber Plants in Upper Egypt. Int. J. Trop. Insect Sci. 2021, 41, 463-469. [CrossRef]

50. Attia, S.; Grissa, K.L.; Lognay, G.; Bitume, E.; Hance, T.; Mailleux, A.C. A Review of the Major Biological Approaches to Control the Worldwide Pest Tetranychus urticae (Acari: Tetranychidae) with Special Reference to Natural Pesticides: Biological Approaches to Control Tetranychus Urticae. J. Pest Sci. 2013, 86, 361-386. [CrossRef]

51. Vicente, C.; Boutaleb, A.; Lebrun, P.H. Quelles Stratégies de Lutte Contre Les Acariens Ravageurs Du Pommier Au Maroc. Parasitica 2003, 59, 25-41.

52. Van Leeuwen, T.; Vontas, J.; Tsagkarakou, A.; Dermauw, W.; Tirry, L. Acaricide Resistance Mechanisms in the Two-Spotted Spider Mite Tetranychus urticae and Other Important Acari: A Review. Insect Biochem. Mol. Biol. 2010, 40, 563-572. [CrossRef]

53. Ball, J.C. Impact of Fungicides and Miticides on Predatory and Phytophagous Mites Associated with Pecan Foliage. Environ. Èntomol. 1982, 11, 1001-1004. [CrossRef]

54. Roy, M. État Actuel De La Lutte Biologique Contre Les Acariens Phytophages Par Des Acariens Prédateurs. Phytoprotection 2005, 74, 41-49. [CrossRef]

55. ONSSA Commission Des Pesticides à Usage Agricole. Available online: http:/ / eservice.onssa.gov.ma/CPUA.aspx (accessed on 10 April 2021).

56. Active, M.; Agro, S.; Pro, M.; Moussem, E.L. Liste Des Pesticides Homologués En Tunisie. 2017. Available online: http: / / www.agridata.tn/dataset/liste-des-pesticides-homologues-en-tunisie (accessed on 22 April 2021).

57. Dar Rehab, A.A.; Hala, H.A. Field Comparison between Tow Natural Compounds and a Common Acaricide on Two-Spotted Spider Mite, Tetranychus urticae and Three of Its Natural Enemies by Using Certain Ground Spraying Equipment on Soybean Crop in Egypt. Egypt. Acad. J. Biol. Sci. 2020, 434, 138-142. [CrossRef]

58. Sato, M.E.; da Silva, M.Z.; Raga, A.; De Souza Filho, M.F. Abamectin Resistance in Tetranychus urticae Koch (Acari: Tetranychidae): Selection, Cross-Resistance and Stability of Resistance. Neotrop. Entomol. 2005, 34, 991-998. [CrossRef]

59. Castagnoli, M.; Liguori, M.; Simoni, S.; Duso, C. Toxicity of Some Insecticides to Tetranychus urticae, Neoseiulus californicus and Tydeus californicus. BioControl 2005, 50, 611-622. [CrossRef]

60. Abo-Elmaged, T.M. Cucumber Plant Mites: Survey and Capacity of Certain Pesticides against the amplest one, Tetranychus urticae Koch, in Assiut area, Upper Egypt. Egypt. Acad. J. Biol. Sciences. A Entomol. 2020, 13, 237-242. [CrossRef] 
61. IRAC Mode of Action Classification I Insecticide Resistance Action Committee (IRAC). Available online: https: / irac-online.org/ mode-of-action/ (accessed on 5 October 2021).

62. Gashout, H.A.; Goodwin, P.H.; Guzman-Novoa, E. Lethality of Synthetic and Natural Acaricides to Worker Honey Bees (Apis mellifera) and Their Impact on the Expression of Health and Detoxification-Related Genes. Environ. Sci. Pollut. Res. 2018, 25, 34730-34739. [CrossRef] [PubMed]

63. Mishra, J.; Arora, N.K. Secondary Metabolites of Fluorescent pseudomonads in Biocontrol of Phytopathogens for Sustainable Agriculture. Appl. Soil Ecol. 2018, 125, 35-45. [CrossRef]

64. Hamza, A.; Mohamed, A.; Derbalah, A. Unconventional Alternatives for Control of Tomato Root Rot Caused by Rhizoctonia Solani under Greenhouse Conditions. J. Plant Prot. Res. 2016, 56, 298-305. [CrossRef]

65. Ruiu, L. Insect Pathogenic Bacteria in Integrated Pest Management. Insects 2015, 6, 352-367. [CrossRef] [PubMed]

66. Osman, M.E.; Abo Elnasr, A.A.; Nawar, M.A.; Hefnawy, G.A. Myco-Metabolites as Biological Control Agents against the Two-Spotted Spider Mite, Tetranychus urticae Koch (Acari: Tetranychidae). Egypt. J. Biol. Pest Control 2019, 29, 64. [CrossRef]

67. Mehdi, H.M.R. The Effect of Some Fungi in Biocontrol in Two Spotted Spider Mite Tetranychus urticae (Koch.) (Tetranychidae: Acari). J. Basrah Res. (Sci.) 2006, 32, 12-26.

68. Hanash, A.A.; Hanawi, M.J.; Hamad, B.S.H. Laboratory Based Bioefficacy of Selected Biopesticides Against the Adults and Nymphs of Two-Spotted Spider Mite Tetranychus urticae Koch (Acari: Tetranychidae). Plant Arch. 2020, $20,3965-3971$.

69. Saenz-De-Cabezon Irigaray, F.J.; Marco-Mancebón, V.; Pérez-Moreno, I. The Entomopathogenic Fungus Beauveria Bassiana and Its Compatibility with Triflumuron: Effects on the Twospotted Spider Mite Tetranychus urticae. Biol. Control 2003, 26, 168-173. [CrossRef]

70. Roobakkumar, A.; Babu, A.; Kumar, D.V. Pseudomonas Fluorescens as an Efficient Entomopathogen against Oligonychus coffeae Nietner ( Acari: Tetranychidae ) Infesting Tea. J. Entomol. 2011, 3, 73-77.

71. Aksoy, H.M.; Ozman-Sullivan, S.K.; Ocal, H.; Celik, N.; Sullivan, G.T. The Effects of Pseudomonas Putida Biotype B on Tetranychus urticae (Acari: Tetranychidae). Exp. Appl. Acarol. 2008, 46, 223-230. [CrossRef]

72. Shoda, M. Bacterial Control of Plant Diseases. J. Biosci. Bioeng. 2000, 89, 515-521. [CrossRef]

73. Basaid, K.; Chebli, B.; Mayad, E.H.; Furze, J.N.; Bouharroud, R.; Krier, F.; Barakate, M.; Paulitz, T. Biological Activities of Essential Oils and Lipopeptides Applied to Control Plant Pests and Diseases: A Review. Int. J. Pest Manag. 2020, 67, 155-177. [CrossRef]

74. Isman, M.B.; Wan, A.J.; Passreiter, C.M. Insecticidal Activity of Essential Oils to the Tobacco Cutworm, Spodoptera litura. Fitoterapia 2001, 72, 65-68. [CrossRef]

75. Hance, T.; Attia, S.; Grissa, K.; Ghrabi-Gammar, Z.; Mailleux, A.; Lognay, G.; Goff, G. Contrôle de Tetranychus urticae Par Les Extraits de Plantes En Vergers d'agrumes. Entomol. Faun. Faun. Entomol. 2010, 63, 229-235.

76. Daniel, C.; Wyss, E.C.L. Applications de Soufre En Automne: Une Nouvelle Manière de Lutter Contre Lériophyide à Galles Du Poirier. Rev. Suisse Vitic. Arboric. Hortic. 2004, 36, 199-203.

77. Boutaleb Joutei, A.; Bassy, F. Essais de Lutte Chimique et Biologique Contre Les Acariens (Tetranychus urticae Koch) et Les Pucerons (Myzus persicae Sulzer) Sur Cultures Maraîchères Dans La Région Du Saïs. Trav. L'institut Sci. Série Zool. 2009. Available online: https://www.researchgate.net/profile/Abdelmalek_Boutaleb_Joutei/publication/321225400_Essais_de_ lutte_chimique_et_biologique_contre_les_acariens_Tetranychus_urticae_Koch_et_les_pucerons_Myzus_persicae_Sulzer_sur_ cultures_maraicheres_dans_la_region_du_Sais (accessed on 28 April 2021).

78. Vacacela Ajila, H.E.; Oliveira, E.E.; Lemos, F.; Haddi, K.; Colares, F.; Marques Gonçalves, P.H.; Venzon, M.; Pallini, A. Effects of Lime Sulfur on Neoseiulus californicus and Phytoseiulus macropilis, Two Naturally Occurring Enemies of the Two-Spotted Spider Mite Tetranychus urticae. Pest Manag. Sci. 2020, 76, 996-1003. [CrossRef]

79. Kreiter, S. Action Du Soufre Sur Les Acariens Phytophages et Prédateurs En Viticulture: Étude Bibliographique et Perspectives de Recherches. 1987. Available online: https:/ / pascal-francis.inist.fr/vibad/index.php?action=getRecordDetail\&idt=8311741 (accessed on 26 June 2021).

80. Guichou, S.; Auger, P.; Kreiter, S. The Acaricidal Effect of Sulfur on Tetranychus urticae (Acari: Tetranychidae) under Laboratory Conditions. Int. Congr. Acarol. 2002. Available online: https://hal.archives-ouvertes.fr/hal-01231316 (accessed on 29 June 2021).

81. Ketoh, G.K.; Koumaglo, H.K.; Glitho, I.A.; Huignard, J. Comparative Effects of Cymbopogon schoenanthus Essential Oil and Piperitone on Callosobruchus Maculatus Development. Fitoterapia 2006, 77, 506-510. [CrossRef] [PubMed]

82. Miresmailli, S.; Bradbury, R.; Isman, M.B. Comparative Toxicity of Rosmarinus officinalis L. Essential Oil and Blends of Its Major Constituents against Tetranychus urticae Koch (Acari: Tetranychidae) on Two Different Host Plants. Pest Manag. Sci. 2006, 62, 366-371. [CrossRef] [PubMed]

83. Kordali, S.; Aslan, I.; Çalmaşur, O.; Cakir, A. Toxicity of Essential Oils Isolated from Three Artemisia Species and Some of Their Major Components to Granary Weevil, Sitophilus granarius L. (Coleoptera: Curculionidae). Ind. Crops Prod. 2006, 23, 162-170. [CrossRef]

84. Roh, H.S.; Lee, B.H.; Park, C.G. Acaricidal and Repellent Effects of Myrtacean Essential Oils and Their Major Constituents against Tetranychus urticae (Tetranychidae). J. Asia-Pac. Entomol. 2013, 16, 245-249. [CrossRef]

85. Cheng, S.S.; Chua, M.T.; Chang, E.H.; Huang, C.G.; Chen, W.J.; Chang, S.T. Variations in Insecticidal Activity and Chemical Compositions of Leaf Essential Oils from Cryptomeria Japonica at Different Ages. Bioresour. Technol. 2009, 100, 465-470. [CrossRef] [PubMed] 
86. Badawy, M.E.I.; El-Arami, S.A.A.; Abdelgaleil, S.A.M. Acaricidal and Quantitative Structure Activity Relationship of Monoterpenes against the Two-Spotted Spider Mite, Tetranychus urticae. Exp. Appl. Acarol. 2010, 52, 261-274. [CrossRef]

87. Park, H.M.; Kim, J.; Chang, K.S.; Kim, B.S.; Yang, Y.J.; Kim, G.H.; Shin, S.C.; Park, I.K. Larvicidal Activity of Myrtaceae Essential Oils and Their Components against Aedes Aegypti, Acute Toxicity on Daphnia Magna, and Aqueous Residue. J. Med. Entomol. 2011, 48, 405-410. [CrossRef]

88. Kordali, S.; Cakir, A.; Ozer, H.; Cakmakci, R.; Kesdek, M.; Mete, E. Antifungal, Phytotoxic and Insecticidal Properties of Essential Oil Isolated from Turkish Origanum Acutidens and Its Three Components, Carvacrol, Thymol and p-Cymene. Bioresour. Technol. 2008, 99, 8788-8795. [CrossRef]

89. Roh, H.S.; Lim, E.G.; Kim, J.; Park, C.G. Acaricidal and Oviposition Deterring Effects of Santalol Identified in Sandalwood Oil against Two-Spotted Spider Mite, Tetranychus urticae Koch (Acari: Tetranychidae). J. Pest Sci. 2011, 84, 495-501. [CrossRef] [PubMed]

90. Ebadollahi, A.; Jalali-Sendi, J.; Razmjou, J. Toxicity and Phytochemical Profile of Essential Oil from Iranian Achillea mellifolium L. against Tetranychus urticae Koch (Acari: Tetranychidae). Toxin Rev. 2016, 35, 24-28. [CrossRef]

91. Abdelgaleil, S.A.M.; Badawy, M.E.I.; Mahmoud, N.F.; Marei, A.E.S.M. Acaricidal Activity, Biochemical Effects and Molecular Docking of Some Monoterpenes against Two-Spotted Spider Mite (Tetranychus urticae Koch). Pestic. Biochem. Physiol. 2019, 156, 105-115. [CrossRef]

92. Brahmi, F.; Adjaoud, A.; Marongiu, B.; Falconieri, D.; Yalaoui-Guellal, D.; Madani, K.; Chibane, M. Chemical and Biological Profiles of Essential Oils from Mentha Spicata L. Leaf from Bejaia in Algeria. J. Essent. Oil Res. 2016, 28, 211-220. [CrossRef]

93. Benelli, G.; Pavela, R.; Canale, A.; Nicoletti, M.; Petrelli, R.; Cappellacci, L.; Galassi, R.; Maggi, F. Isofuranodiene and Germacrone from Smyrnium olusatrum Essential Oil as Acaricides and Oviposition Inhibitors against Tetranychus urticae: Impact of Chemical Stabilization of Isofuranodiene by Interaction with Silver Triflate. J. Pest Sci. 2017, 90, 693-699. [CrossRef]

94. Attia, S.; Grissa, K.L.; Zeineb, G.G.; Mailleux, A.C.; Lognay, G.; Hance, T. Assessment of the Acaricidal Activity of Several Plant Extracts on the Phytophagous Mite Tetranychus urticae (Tetranychidae) in Tunisian Citrus Orchards. Bull. Soc. R. Belg. D'entomologie 2011, 147, 71-79.

95. Han, J.; Kim, S.I.; Choi, B.R.; Lee, S.G.; Ahn, Y.J. Fumigant Toxicity of Lemon Eucalyptus Oil Constituents to Acaricide-Susceptible and Acaricide-Resistant Tetranychus Urticae. Pest Manag. Sci. 2011, 67, 1583-1588. [CrossRef]

96. Hamdi, S.H.; Hedjal-Chebheb, M.; Kellouche, A.; Khouja, M.L.; Boudabous, A.; Ben Jemâa, J.M. Management of Three Pests' Population Strains from Tunisia and Algeria Using Eucalyptus Essential Oils. Ind. Crops Prod. 2015, 74, 551-556. [CrossRef]

97. Attia, S.; Grissa, K.L.; Lognay, G.; Heuskin, S.; Mailleux, A.C.; Hance, T. Chemical Composition and Acaricidal Properties of Deverra scoparia Essential Oil (Araliales: Apiaceae) and Blends of Its Major Constituents against Tetranychus urticae (Acari: Tetranychidae). J. Econ. Entomol. 2011, 104, 1220-1228. [CrossRef] [PubMed]

98. Laborda, R.; Manzano, I.; Gamón, M.; Gavidia, I.; Pérez-Bermúdez, P.; Boluda, R. Effects of Rosmarinus officinalis and Salvia officinalis Essential Oils on Tetranychus urticae Koch (Acari: Tetranychidae). Ind. Crops Prod. 2013, 48, 106-110. [CrossRef]

99. Ahmadi, Z.; Saber, M.; Bagheri, M.; Mahdavinia, G.R. Achillea Millefolium Essential Oil and Chitosan Nanocapsules with Enhanced Activity against Tetranychus Urticae. J. Pest Sci. 2018, 91, 837-848. [CrossRef]

100. Smaili, M.C.; Abbassi, M.; Boutaleb, J.A.; Blenzar, A. Richesse Spécifique Des Ennemis Naturels Associés Aux Vergers d’agrumes Au Maroc: Intérêt et Implication Pour La Lutte Biologique. EPPO Bull. 2013, 43, 155-166. [CrossRef]

101. Albendín, G.; García, M.D.C.; Molina, J.M. Multiple Natural Enemies Do Not Improve Two Spotted Spider Mite and Flower Western Thrips Control in Strawberry Tunnels. Chil. J. Agric. Res. 2015, 75, 63-70. [CrossRef]

102. Kazak, C.; Karut, K.; Doker, I. Indigenous Populations of Neoseiulus californicus and Phytoseiulus persimilis (Acari: Phytoseiidae): Single and Combined Releases against Tetranychus urticae (Acari: Tetranychidae) on Greenhouse Eggplant. Int. J. Acarol. 2015, 41, 108-114. [CrossRef]

103. Croft, B.A.; Monetti, L.N.; Pratt, P.D. Comparative Life Histories and Predation Types: Are Neoseiulus californicus and N. fallacis (Acari: Phytoseiidae) Similar Type II Selective Predators of Spider Mites? Environ. Entomol. 1998, 27, 531-538. [CrossRef]

104. El Laithy, A.Y.M.; El Sawi, S.A. Biology and Life Table Parameters of the Predatory Mite Neoseiulus californicus Fed on Different Diet/Biologie Und Lebenstafel-Parameter Der Raubmilbe Neoseiulus californicus Bei Unterschiedlicher Ernährung. Z. Pflanzenkrankh. Pflanzenschutz 2016, 105, 532-537.

105. Bouharroud, R. Acariens Clés Des Agrumes Au Maroc, Agriculture Du Maghreb. Available online: http://www.agri-mag.com/ 2017/06/acariens-cles-des-agrumes-au-maroc/ (accessed on 18 April 2021).

106. Kreiter, S.; Sahraoui, H.; Lebdi-Grissa, K.; Chermiti, B.; Khoualdia, O.; Ksantini, M. Phytoseiid Mites (Acari: Mesostigmata) from Tunisia: Catalogue, Biogeography and Key for Identification. Tunis. J. Plant Prot. 2008, 5, 151-178.

107. Cruz-Miralles, J.; Cabedo-López, M.; Guzzo, M.; Ibáñez-Gual, V.; Flors, V.; Jaques, J.A. Plant-Feeding May Explain Why the Generalist Predator Euseius stipulatus Does Better on Less Defended Citrus Plants but Tetranychus-Specialists Neoseiulus californicus and Phytoseiulus persimilis Do Not. Exp. Appl. Acarol. 2021, 83, 167-182. [CrossRef]

108. Ferragut, F.; Garcia-Marí, F.; Costa-Comelles, J.; Laborda, R. Influence of Food and Temperature on Development and Oviposition of Euseius stipulatus and Typhlodromus phialatus (Acari: Phytoseiidae). Exp. Appl. Acarol. 1987, 3, 317-329. [CrossRef]

109. McMurtry, J.A. Some Predaceous Mites [Phytoseiidae] on Citrus in the Mediterranean Region. Entomophaga 1977, 22, 19-30. [CrossRef] 
110. Adly, D. Use of Predators for Controlling the Whitefly, Bemisia Tabaci Genn. And the Two Spotted Spider Mite, Tetranychus urticae Koch., in Cucumber Greenhouses in Egypt. Egypt. J. Biol. Pest Control 2016, 26, 701-706.

111. Smaili, M.C.; Boutaleb-Joutei, A.; Blenzar, A. Beneficial Insect Community of Moroccan Citrus Groves: Assessment of Their Potential to Enhance Biocontrol Services. Egypt. J. Biol. Pest Control 2020, 30, 47. [CrossRef]

112. Bouagga, S.; Urbaneja, A.; Pérez-Hedo, M. Combined Use of Predatory Mirids with Amblyseius swirskii (Acari: Phytoseiidae) to Enhance Pest Management in Sweet Pepper. J. Econ. Entomol. 2018, 111, 1112-1120. [CrossRef]

113. Abad-Moyano, R.; Pina, T.; Dembilio, Ó.; Ferragut, F.; Urbaneja, A. Survey of Natural Enemies of Spider Mites (Acari: Tetranychidae) in Citrus Orchards in Eastern Spain. Exp. Appl. Acarol. 2009, 47, 49-61. [CrossRef]

114. Roy, M.; Brodeur, J.; Cloutier, C. Seasonal Activity of the Spider Mite Predators Stethorus punctillum (Coleoptera: Coccinellidae) and Neoseiulus fallacis (Acarina: Phytoseiidae) in Raspberry, Two Predators of Tetranychus mcdanieli (Acarina: Tetranychidae). Biol. Control 2005, 34, 47-57. [CrossRef]

115. Guo, Y.Y.; Tian, J.C.; Shi, W.P.; Dong, X.H.; Romeis, J.; Naranjo, S.E.; Hellmich, R.L.; Shelton, A.M. The Interaction of TwoSpotted Spider Mites, Tetranychus urticae Koch, with Cry Protein Production and Predation by Amblyseius andersoni (Chant) in Cry1Ac/Cry2Ab Cotton and Cry1F Maize. Transgenic Res. 2016, 25, 33-44. [CrossRef] [PubMed]

116. Kumar, V.; Mehra, L.; Mckenzie, C.L.; Osborne, L.S. "Predator-In-First": A Preemptive Biological Control Strategy for Sustainable Management of Pepper Pests in Florida. Sustainability 2020, 12, 7816. [CrossRef]

117. Vincent, C.; Panneton, B. Les Méthodes de Lutte Physique Comme Alternatives Aux Pesticides 2001. Available online: http: / /journals.openedition.org/vertigo/4093 (accessed on 16 April 2021).

118. Raza, M.F.; Yao, Z.; Dong, X.; Cai, Z.; Zhang, H. Citrus Insect Pests and Their Non Chemical Control in China. Citrus Res. Technol. 2017, 38, 122-138. [CrossRef]

119. Unruh, T.R.; Knight, A.L.; Upton, J.; Glenn, D.M.; Puterka, G.J. Particle Films for Suppression of the Codling moth (Lepidoptera: Tortricidae) in Apple and Pear Orchards. J. Econ. Entomol. 2000, 93, 737-743. [CrossRef] [PubMed]

120. Fields, P.; Korunic, Z.; Fleurat-Lessard, F. Control of Insects in Post-Harvest: Inert Dusts and Mechanical Means. In Physical Control Methods in Plant Protection; Springer: Berlin/Heidelberg, Germany, 2001; pp. 248-257. [CrossRef]

121. Kim, Y.; Lounds-Singleton, A.J.; Talcott, S.T. Antioxidant Phytochemical and Quality Changes Associated with Hot Water Immersion Treatment of Mangoes (Mangifera indica L.). Food Chem. 2009, 115, 989-993. [CrossRef]

122. Tanaka, M.; Yase, J.; Aoki, S.; Sakurai, T.; Kanto, T.; Osakabe, M. Physical Control of Spider Mites Using Ultraviolet-B with Light Reflection Sheets in Greenhouse Strawberries. J. Econ. Entomol. 2016, 109, 1758-1765. [CrossRef] [PubMed]

123. Murata, Y.; Osakabe, M. The Bunsen-Roscoe Reciprocity Law in Ultraviolet-B-Induced Mortality of the Two-Spotted Spider Mite Tetranychus urticae. J. Insect Physiol. 2013, 59, 241-247. [CrossRef]

124. Osakabe, M. Biological Impact of Ultraviolet-B Radiation on Spider Mites and Its Application in Integrated Pest Management. Appl. Entomol. Zool. 2020, 56, 139-155. [CrossRef]

125. Capinera, J.L. Encyclopedia of Entomology-Google Livres. Available online: https://books.google.co.ma/books?hl=fr\&lr= \&id=i9ITMiiohVQC\&oi=fnd\&pg=PR55\&dq=The+Encyclopedia+of+Entomology\&ots=VZzrSwiOOP\&sig=DzVOD23SXJT2 fxfFgmAx_dDFgdw\&redir_esc=y\#v=onepage\&q=The-Encyclopedia-of-Entomology\&f=false (accessed on 16 April 2021).

126. Bouyer, J. Lutte Intégrée Contre Les Insectes Vecteurs de Maladies Humaines et animales. Développer Lutte Génétique 2014, $34,4$.

127. Estrella Santamaria, M.; Arnaiz, A.; Rosa-Diaz, I.; González-Melendi, P.; Romero-Hernandez, G.; Ojeda-Martinez, D.A.; Garcia, A.; Contreras, E.; Martinez, M.; Diaz, I. Plant Defenses against Tetranychus urticae: Mind the Gaps. Plants 2020, 9, 464. [CrossRef]

128. Lilley, R.; Campbell, C.A.M. Biological, Chemical and Integrated Control of Two-Spotted Spider Mite Tetranychus urticae on Dwarf Hops. Biocontrol Sci. Technol. 2010, 9, 467-473. [CrossRef]

129. Nicetic, O.; Watson, D.M.; Beattie, G.A.C.; Meats, A.; Zheng, J. Integrated Pest Management of Two-Spotted Mite Tetranychus urticae on Greenhouse Roses Using Petroleum Spray Oil and the Predatory Mite Phytoseiulus Persimilis. Exp. Appl. Acarol. 2001, 25, 37-53. [CrossRef] [PubMed]

130. Iwassaki, L.A.; Sato, M.E.; Calegario, F.F.; Poletti, M.; Maia, A. de H.N. Comparison of Conventional and Integrated Programs for Control of Tetranychus urticae (Acari: Tetranychidae). Exp. Appl. Acarol. 2014, 65, 205-217. [CrossRef] [PubMed]

131. Jones, G.; Campbell, C.A.M.; Hardie, J.; Pickett, J.A.; Pye, B.J.; Wadhams, L.J. Integrated Management of Two-Spotted Spider Mite Tetranychus urticae on Hops Using Hop $\beta$-Acids as an Antifeedant Together with the Predatory Mite Phytoseiulus persimilis. Biocontrol Sci. Technol. 2003, 13, 241-252. [CrossRef] 